\title{
Trauma and Community
}

\section{Katarina Možina and Katarina Kompan Erzar}

Sigmund Freud University Vienna/Ljubljana

\begin{abstract}
This article presents an example of trauma recovery and post-traumatic growth in the story of three generations of a family that lost five sons in World War II and post-war mass killings, experienced the imprisonment of one son and the emigration of two daughters, expropriation of their possessions, and postwar communist harassment. With the help of the village community, the connection between family members, and because of their inherent faith, the pain of trauma has been transformed through three generations into national awareness, courage, emotional vulnerability, and creativity. In Slovenia, there are a few examples of villages that resisted partisan violence against the population and held out against the communist revolution but paid for it with several people who were killed, abducted, or imprisoned. These villages became a source of national consciousness and political social activity and strongly supported Slovenia in 1990 in the process of gaining independence from Yugoslavia. In most of these villages, affiliation with the Roman Catholic Church, the connection between the village community, and the connection between the younger generations and the older ones are also strong. We will present the stories of three women, a grandmother, a mother, and a daughter, and through their narration illustrate the process of moving from PTSD to post-traumatic growth.
\end{abstract}

\section{Keywords}

memory; intergenerational transmission of trauma; recovery; posttraumatic growth; community

\section{Introduction}

In countries in the post-communist era, we are often faced with broad traumatization and intimidation that haunt people even long after the collapse of the communist regime. The Slovenian public has only recently begun to understand the profound consequences of the tragic events that occurred during and after the Second World War when thousands of anticommunist militiamen and civilians were killed and thrown into mineshafts and mass

\footnotetext{
* Katarina Možina, Sigmund Freud University Vienna/Ljubljana; Katarina Kompan Erzar (corresponding author), Sigmund Freud University Vienna/Ljubljana, Trubarjeva 65, 1000 Ljubljana; University of Ljubljana - Faculty of Theology, Poljanska 4, 1000 Ljubljana; lia-katarina.kompan@guest. arnes.si
} 
graves. This tragedy has had far-reaching psychological, social, and cultural effects on the first- and second-generation survivors, affecting their personal coping, interpersonal skills, family relationships, and the experience of these relationships (Dežman, 2012). In this article we will present a story of e.g., a typical family that suffered from communist oppression during and after the Second World War'.

\section{Social Aspects of Trauma Narrative}

Trauma has many different faces and marks all facets of human life; society, interpersonal relationships, and the intrapsychic world. We could say with Van der Kolk (1996) that victims are members of society whose problems represent the memory of suffering, rage, and pain in a world that longs to forget. That is why in many countries trauma remained unresolved. Social trauma, (war trauma or the trauma resulting from what took place under totalitarian regimes) not only marks the individual and their family. The impact of it is much broader, as much of the pain is related to the wider social context; coping with social pain is, according to Možina (2009), “...just as important as coping with one's own pain" (p. 118). Whether the identifications formed by individuals for survival will remain largely unconscious and a source of conflict depends a lot on the social climate, that is, the influences of the environment and social structures that maintain or resolve the mechanisms of transmission of traumatic experiences. In totalitarian regimes, the intimidation and silencing of the victims produce a great amount of suppressed anger, fear, and shame that burdened generations of people. So it is easy to understand that unresolved losses and untold traumatic stories blocked the healing of the society since it took great courage and risk to speak openly about massive trauma. Many authors claim, that keeping secrets and suppressing information heavily burdens the body. Van der Kolk (2014) calls that state as being at war with oneself. To get over that state, it takes an enormous amount of courage that allows you to finally know what you know. When victims begin to speak about their traumatic past and the conspiracy of silence is broken, a broad range of feelings flood the entire society and individuals. When the victim doesn't fear to speak anymore and begin to create a narrative that reveals the truths about past trauma, there can be an unpredictable mixture of anxiety, guilt, shame, sadness on the one side, as Kellerman (2009) observes, and compassion for the victim's pain, the shame felt by passive observers, and denial and guilt felt by perpetrators. Many

1 The stories, including quotes from the actors of these stories, as well as the general content of this article, are part of research for a PhD disertation at Sigmund Freud University in Vienna. 
researchers who address the transgenerational transmission of trauma, (e.g., Kestenberg, J. S. and M., 1982; Weingarten, 2004; Kellerman, 2009; Bezo and Maggi, 2015) point out, that with the breaking the silence, questions also arise about the need for individual and collective responsibilities that can pave the way for reconciliation and normalization (Kellerman, 2009).

According to some Slovenian researchers (e.g., Dežman, 2004; Možina, 2019) in Slovenia, the public glorification of communist totalitarian symbols and their bearers has contributed to the preservation of traumatic content in the last decade.

Given that people thrive only when they feel good about themselves and live in secure relationships (Fredricson, 2012), it is our position that dealing with this trauma is a matter of national survival. The prerequisite for trauma recovery is mourning and compassionate intergenerational solidarity. Until they are met, the members of society will be marked by broken relationships, suppressed despair, false courage, and various forms of violence and self-destructive behavior (Kompan Erzar, 2017). Research on the emotional consequences of traumatic experiences related to the war in three generations shows that the consequences for each family may be different, ranging from sadness, anger, and shame to pride, resilience, and gratitude. Creating a narrative that is emotionally regulated and historically accurate is a multigenerational task. It is nevertheless possible to describe some general characteristics for each of the postwar generations (Kahane-Nissenbaum, 2011).

For the generation directly affected by war traumas (the "first generation"), stopping the trauma is the first and most important task. Because post-war years are usually spent in securing personal safety and rebuilding homes, little attention is paid to how people feel inside. The task at hand for the generation of descendants of children of war (the "second generation") is less about securing physical survival and more of an emotional one (Albeck, 1994). The lives of people of this generation are focused on family relationships in the hope that they will provide a secure base for safe attachment. To the generation of children born to the children of traumatized parents (the "third-generation"), the trauma of the Second World War is a distant and little-known memory of their grandparents. In Slovenia, this generation was mainly born after the collapse of the Yugoslav communist regime in 1990 and was mostly not directly affected by the culture of fear. It also no longer orients itself to the past, nor does it worry about the well-being of the parents (Kompan Erzar, 2017). Their task is to know themselves better, turn to the world, and dream about the creation of a new one. The members of this generation often have a very subtle feeling for art, creativity, and a vision for the future. Their success 
in life, however, depends greatly on the successful reworking of trauma in previous generations (Kahane-Nissenbaum, 2011).

If we follow the development of the narrative the generations establish, we could extract the main themes each family who successfully resolved traumatic past, created. Through those themes, we then discover the sources of their posttraumatic growth.

\section{First Step of Narrative Formation: Preserving the Memory and Collecting Stories}

The survivors of World War II and post-war trauma are dying and we are losing the last first-person witnesses, members of the generation that survived the horrors of World War II and totalitarian regimes. Their stories will only be quickly shared by members of the second, third, perhaps fourth generation. And even if they speak with the words of the dead, they will inevitably mix their own words as well (Rosner, 2017).

So we are faced with the question of how to preserve stories that have never been told openly. Stories were not lost because of the destroyed memories of the murdered, but because of the fading memory of the living. Or, as Mendelsohn (2006) says, one is sometimes more afraid of forgetting their parents' stories than of losing track of their own story. If we don't collect the stories, how should the present generations tell of what could not have been, and yet should be uttered, thus protecting the memory of the victims, so that the imposition of silence by those who killed them does not cause the victims to be killed a second time? That question was raised by Elie Wiesel (in Rosner, 2017). On the other hand, there are also more and more people who are tired of repeating stories from our common history and believe that this prevents them from enjoying the present in a relaxed way. Rosner (2017) openly questions the consequences of this dying conversation and resistance to storytelling on someone who has survived a traumatic experience and whose entire adult life has been devoted to preserving a lesson about the past that gave meaning to their survival. It is important to know how to tell those stories in such a way that further generations could benefit from them and understand them as a gift of the previous generation, a generation that enables their life by surviving and thriving. The meaning of remembrance is articulated by $\mathrm{E}$. Wiesel (in Rosner, 2017): "Our future depends on our testimony... To forget Auschwitz is to justify Hiroshima - the next Hiroshima. It's a paradox: only Auschwitz can save the planet from a new Hiroshima" (p. 213). What we do not articulate, or shape into a narrative, threatens to be repeated (Kompan Erzar, 2012). 
By remembering, we not only prevent a possible recurrence of evil but also destroy its purpose in the past. The task of present and future generations is to understand past experiences in order to more easily predict and respond to the future (Wigram, 1994).

Whether we admit it or not, the past of our ancestors is also a part of us. Marianne Hirsch (2008) introduced the concept of post-memory, or aftermemory, which argues that stories and memory that are not ours nevertheless shape us greatly. As Rosner (2017) points out, to keep the past within the present with a sense of acceptance rather than resistance, we can commit it to a healthy memory.

The family after-memory includes vertically inherited stories and memories of parents and other relatives and a partners' after-memory that extends horizontally to the public and the collective. Both aspects need to be considered in the processing of trauma and memory, and the approach to this area of research should become increasingly interdisciplinary (Hirsch, 2008). The heritage of the people is broadly studied by several authors (e.g., SagiSchwartz, 2003; Lev-Wiesel, 2007) who have included third-generation studies to find an answer to the question, what they carry with them from the past to the future, what is the scale of the wave of trauma through the generations. "Taking into consideration that it is hard to study the influence of the Holocaust on the first generation, and even more so upon the second generation, the studies on the third generation become very challenging, indeed" (Kellerman, 2009, loc. 2007).

With researching the third generation of survivors, the process of transgenerational transmission of trauma reveals that in addition to the first, trauma also damages future generations. But the effects of trauma may become less obvious over time and be more difficult to identify than in earlier generations. Of course, even the third generation may still be affected by ancestral history, but how much and in what way depends on several factors. One of the most obvious factors is closer contact with the first generation, which can cause unpleasant feelings but can also bring relief or help and open the door to the inner world of the elderly. For them it often seems easier to open up to their grandchildren and let them in their world of stories that were previously avoided, helping them finally to face their past. Another important factor is also the number of years they spend together and the way they talk about the traumatic experience. (Kellerman, 2009).

Sophie Richman (2002) in her book Wolf in the attic, the legacy of hidden children of holocaust, points out, that children were more affected by adult behavior and ability to remain kind and warm toward them than by 
reality around them. Each generation could make a step further enabling their offspring to make a deeper connection with the emotional side of the traumatic past and to connect freely with the ancestors (Erzar, 2015). A study by Sigel and Weinfeld (1989) found that the third generation has a higher level of psychological well-being than the second generation, but also a higher level of identification with the first generation, which they associate with a greater subjective sense of third-generation security that makes it easier to identify with the identity and story of grandparents. Some other cultural, religious, and historical manifestations of the trauma were also observed in the grandchildren, such as the glorification of the life and achievements of the grandparents in whom they see their role models. Grandchildren can see their grandparents as victorious survivors and attribute to them special abilities that helped them through the worst hardships. This helps the third generation to be able to make the trauma of their grandparents into a part of themselves, as something that can suit them, and not as something that others have passed on to them (Rosner, 2017).

But there are also other possibilities as a study of transgenerational content among Armenians who survived the Turkish genocide in 1915 (Kupelian et al. 1998, in Lev-Wiesel, 2007) showed: The third generation carries more pathological symptoms than the second generation. Other studies have also shown the transmission of trauma to the children of Vietnamese men whose fathers were World War II veterans (Lev-Wiesel, 2007).

Although there may be no clear signs of traumatization of the third generation or they are not aware of them, they can still be seen in certain situations. One such sign for instance is existential fear, with the ever-present elements of death and survival, which many are only aware of in moments of danger or crisis, but which can also be part of normal, everyday feelings. As van der Kolk (2014) points out, trauma is not just an event that took place sometime in the past. It is also the imprint left by that experience on the mind, brain, and body. This imprint has ongoing consequences for how the human organism manages to survive in the present. The fundamental reorganization of the way the mind and brain manage perceptions is changed due to traumatic experiences. It changes not only how we think and what we think about but also our very capacity to think. That is why traumatic experience is directly transmitted between generations.

Kellerman (2009) concludes that mental health outcomes in the third generation are similar to those of the second generation, when we cannot always show clear signs of trauma transmission, but it is indicated by specific mitigating and aggravating factors. 


\section{The Second Step of Narrative Formation: Processing Trauma Through Story Sharing}

Sharing stories is the fundamental means of human cultural development and emotional survival. It is an individual's personal choice whether to share their stories or not, but choosing to share their stories has many advantages for the narrator, especially when he or she encounters a supportive listener. There are many benefits of revealing stories since, feeling heard and understood helps the narrator to articulate complex feelings (Van der Kolk, 2014).

Rosner (2017) emphasizes that the process of narration enables the narrator to find the meaning of their survival and to find their mission for the rest of his life. Through storytelling or writing, an individual can effectively integrate repressed and alienated content (Kompan Erzar, 2019). McGoldrick (2004) and Werner-Lin and Moro (2004) find out that storytelling makes it possible to mourn the loss and move forward.

The most valuable benefit of narration is the regulation of the fear and shame effect. As long as the story remains a secret it can arouse feelings that something shameful has happened or that the one who has had an experience is bad or will be punished (Scheff, 2000). Narration can lead to the reshaping of traumatic beliefs that are situational in nature (time, circumstances) and not personal (weakness, distrust). Retelling the story over and over again and making it more and more resolved, the reactivity or intensity of recalling memories, which is the result of unprocessed traumatic memories, decreases. By creating a regulated narrative of the traumatic event, we can differentiate ourselves from the traumatic content and we can also see that our reactions were appropriate to the circumstances: increased activity of the nervous system has the function of protecting us from possible similar danger in the future (Porges, 2013). When confronted with trauma through storytelling, which requires the strength and courage of a survivor, fear can be reduced and a greater sense of freedom and wholeness can emerge. Neuroscientific research shows that the only way that can change the way people feel is by helping them to be aware of their inner experience. To help them learn to befriend what is going inside themselves (van der Kolk, 2014). The main problem with traumatic memories is, that they are often disorganized, in fragments, the narrative is vague, and it is difficult to capture the broader context. Making a coherent narration and articulating a traumatic experience, is a prerequisite to recover memory and make it organized into a chronological story of events, a proper meaning, and the ability to include also the victim's reactions, and thus become more manageable and less threatening. One of the greatest benefits of narrating a traumatic experience is processing a difficult event in 
such a way that it begins to make sense to the victim (Van der Kolk, 2014; Gillihan, 2019).

With the help of the concept of the core language, we can conclude that it helps to change undeclared memory into declared memory by helping a person to connect events and experiences that they could not integrate or even remember before. In this way, a person slowly begins to understand what happened to them or someone close to them, and experiences and emotions make sense (Wolynn, 2017). "Once we locate their origin in the past, in our trauma or in a family trauma, we can stop living them as though they belong in the present" (Wolynn, 2107, p. 56).

\section{Third Step of Narrative Formation: Connecting with Traumatic Narratives in Society and in the Family}

The benefits of story-telling for the narrator are quite obvious and well researched. But there is also a great benefit for the listeners of those narratives. Since the stories are often told in the family or community we must be aware of the fact, that when we enter into the role of a listener, we become recipients of the narrator's memories, we become witnesses. Cvetek (2010) in his work states that the story can help the listener understand the narrator's suffering, while at the same time allowing the narrator to reduce the feeling of isolation induced by the trauma. For this to happen, there must be an identification with the main actor, which allows the perspective to be heard and now accepted.

The role of the listener is not easy since it demands empathy and the ability to bear the emotional side of the story that is told. According to Rosner (2017), it takes courage to ask questions, since there exists the fear of knowing too much or of arousing unpleasant feelings in the narrator, or the listeners are not interested enough in the story because they find the life of narrators remote and irrelevant.

The listener cannot choose which versions of the stories they would like to hear: those that are easier for the victims or perhaps for the perpetrators, those for the survivors or those for their descendants, those about the past or perhaps those about the present and the future? So the listener is the one, according to Rosner (2017), that is obliged, without condemnation, simply to listen, because if the listener, due to their (hidden) resistance or condemnation, tries to hide from the narrative, regardless of whether they are a victim or a perpetrator, we will never know the wider truth about humanity: about recurring and transmitted traumas, about what each of us can endure and also how much evil can be done under certain circumstances. To connect 
with the narrative is not easy, but very valuable and crucial in the process of learning from the atrocities in order not to repeat them.

The same holds for the family. According to McGoldrick (2011), we are not only born into a family but also into its stories. These stories may divide families by creating intergenerational cut-offs or promote healing and enabling deep emotional connection. As Werner-Lin and Moro (2004) write:

"Sharing memories and stories can help family members develop more benign, less traumatic perspectives on the role of those in their lives. Such sharing help them tolerate their own and each other's different emotional reactions to the loss, patterns of mourning, and pathways for moving on" (p. 314).

When the family can freely remember as well as to let go of memories there is a place for creating family stories and clarifying its history. We could state that the family that is left without stories that would give meaning to their experience will be stuck in unresolved mourning (Werner-Lin and Moro, 2004). The next generation thus remains isolated and lost, without a pattern for the integration of later losses.

Family stories are usually told to protect the offspring from the dangerous world and to promote the family beliefs that need to be respected. Thus family myths about the dangers of the outside world that flow through generations are created. Only when people are aware of the underlying family story can they decide whether or not to maintain certain behavior, beliefs, and roles. To be aware that family myths are necessary since they hold the power to influence the next generation, which can unconsciously accept these beliefs as reality. (McGoldrick, 2011).

\section{The Forth/Last Step of Narrative Formation is Going From Personal Processing of Trauma to Social Change}

We have seen that the narrative formation goes from sharing stories to connecting and strengthening interpersonal relationships and intrapsychic emotional regulation. Regulated individuals who can connect with others then form a more balanced society. Traumatic stories thus come back to society as a balanced, emotionally regulated, and genuine narrative of the atrocities that happened in the past. In that manner, humanity could mourn its losses, develop respect and dignity and also face the dark side of human history to learn to live better.

To accept atrocious reality is a hard and painful task, since, as van der Kolk (2014) points out that the core issue in trauma is reality, unlike other forms of psychological disorders. The long and hard path from trauma to recovery 
and posttraumatic growth that individuals must endure thus helps create safety and connects families who could then create a safer society. For van der Kolk (2014) safe connections are fundamental to a meaningful and satisfying life and the ability to feel safe with other people is probably the single most important aspect of mental health.

Finding a responsive community in which an individual can share their truth, and their story or the story of a family recognized as valid, is, according to several researchers (Werner-Lin and Moro, 2004; Rolland, 2004; Van der Kolk, 2014), an important part of the community healing process. When stories of social tragedy can become part of a collective story, the narrator can once again feel that they are a member of a community.

"When the dominant narrative is narrow, rigid, or marginalizes segments of the population.... The greater victims are invariably those people who do not have a voice, whose story is excluded, and who are further victimized after a collective tragedy" (Salvatici, in Landau and Saul, 2004, p. 304).

To understand the trauma, it is necessary to overcome natural resistance, face reality, and cultivate the courage to listen to the testimonies of survivors. Trauma is inherently overwhelming and difficult, and any recollection requires us to "...suspend our sense of what is normal and accept that we are dealing with a dual reality: the reality of a relatively secure and predictable present that lives side by side with a ruinous, ever-present past" (Van der Kolk, 2014, p. 195). An open narration helps society step out of the dichotomy of black and white and to recognize the diversity of life stories thus creating a more comprehensive and meaningful thrust about the world. Rosner writes (2017), that we know of individuals within the totalitarian system who caused the deaths of hundreds, thousands of people, and we know that many participated in a collective crime by not saying, intervening, or doing anything, but in the same system there were also families, communities and entire villages who risked their lives to save many doomed to suffering and death.

In our article, we will trace three generations of the family from such a village. We want to illustrate the multigenerational creation of the narrative and development of the family mission which enables them to cross the path from being a victim to become an active participant and creator of social truth.

\section{Research Question}

The focus of our research was to present a case study of a family who manages to create narratives that enable them to process and resolve traumatic past and develop post-traumatic growth.

Considering this background, we further explored: 
- What were the main themes of the family narrative?

- How was (transgenerational) trauma perceived and communicated?

- What were the pillars of the trauma recovery narrative?

- How (transgenerational) trauma affected their identities, actions, and relationships?

- Which were the signs of posttraumatic growth that occurred through generations?

\section{Method}

We addressed the research questions through in-depth interviews with a victim of war and post-war violence and representatives of two generations of her descendants, namely her daughter and granddaughter. We conducted interviews in the second half of 2018, but we followed the issue of the village for a long time: we had several informal conversations with the villagers, visited the memorials in the village commemorating communist violence during and after the war, attended a memorial ceremony for killed home guards and civilians from this village... In addition, we systematically researched documents that provided a source of information about what was happening in the village at the time mentioned by the interviewees in their narratives. These are mainly private notes and diaries, public testimonies (on radio and television), published articles and books on the topic, and preserved archival material.

The main question was how victims of totalitarian regimes during and after WWII experienced the traumatic events and how their descendants see/feel the impact of that experience on their own lives.

Interviews were audiotaped, transcribed, and analyzed. We extracted the main pillars of trauma recovery narrative formation and the main themes of posttraumatic growth. By following them we showed the process of gradual recovery and posttraumatic growth through three generations.

Participants:

From our study, we chose three generations of women from a Slovenian family who survived communist oppression and managed to thrive. They live in Slovenia and suffered trauma because of anti-communist activity and were marginalized by the communist regime long after the war ended.

We chose them according to the presented inclusion criteria:

Table 1: Inclusion criteria for our study 
Journal of Nationalism, Memory \& Language Politics 15(1)

\begin{tabular}{|l|l|}
\hline Gender & Female \\
\hline Age of 1 generation & Born before 1941 \\
\hline Age of 3 generation & At least 15 years \\
\hline Nationality and language & Slovene \\
\hline $\begin{array}{l}1 \text { generation identified as a victim of war } \\
\text { and/post-war communist regime }\end{array}$ & Yes \\
\hline Willingness to share the story and consent & Yes \\
\hline Written consent & Yes \\
\hline
\end{tabular}

\section{Introduction and Presentation of the Family}

Mary (grandmother), Jane (mother/daughter) and Sara (daughter/granddaughter)

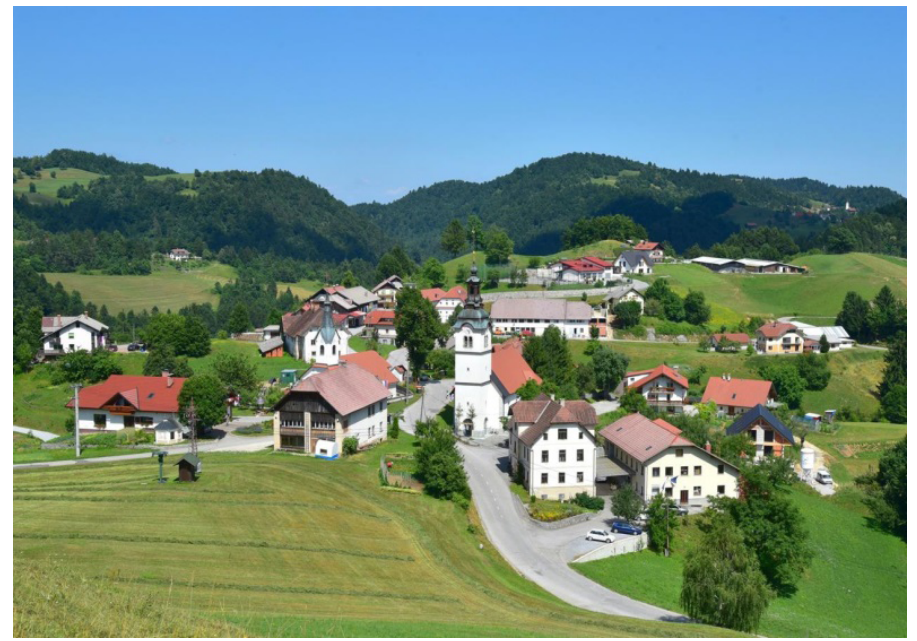

Fig.1: Photo of a village in the central Slovenian region, where family B lives and which has been brutally encroached upon by the violence of war and communist regime (source: https://sl.wikipedia.org).

The family comes from a romantic village in central Slovenia, which appearance is in sharp contrast with atrocities held there during the war and post-war communist regime. The village of socially active, connected, and patriotic community was shocked by partisan aggression and developed the first village guard in Slovenia.

The family of 14 children, one of them is our oldest research participant Mary (born in 1941) entered the war as a culturally active and educated family. As 
a member of village guards, her father was arrested immediately after the war and put to a work camp, the experience that left devastating scars on his life. They also lost their workshop and land and hardly survived with the help of their relatives who immigrated to the USA: Mary saw her relatives only in 1974. She was not even 20 years old when she got married to a neighbor from the village who lost five of his brothers in the post-war killings. Almost all men of the village were killed.

Mary and her husband had five children (born between 1962 and 1981) and 17 grandchildren. All of them remained in the village and help it to recover. Very few villagers chose to leave the village since they remained strongly connected with the place. Most of them also share religious and worldview beliefs. At Mary's home, they talked a lot about socio-political topics and also worked hard to keep the village alive.

Her daughter Jane (born in 1965), now a historian, as a child had no fear telling her history teacher what she knew of the "forbidden truth" of war and post-war events. After finishing her studies, she became actively involved in party politics, where she also met her husband.

Mary and Jane with her families are living together in a big family house. Jane has three daughters and the oldest, Sara (our third participant in the study, born in 1995)), is a student.

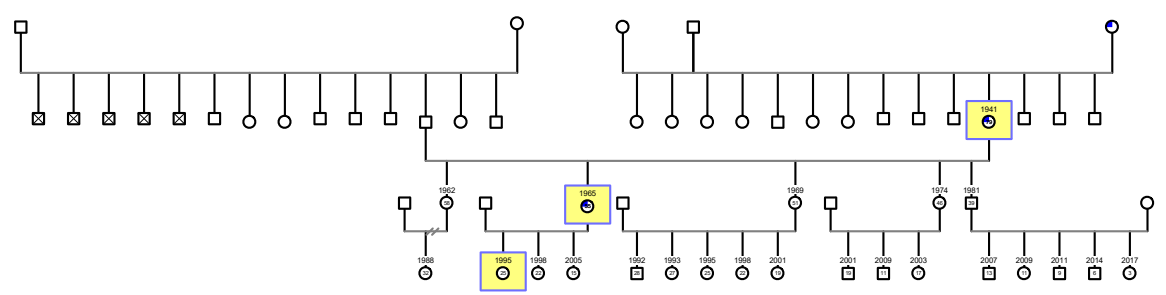

Fig. 2: Genogram of the family in which the interviewees in the research (generations 1-3) are marked. In Generation 1, the symbols for those killed in post-war massacres are crossed.

The village community represented a safe social framework, and since everybody in the village was traumatized each house lost some of its members and some property. But the ability to tell stories and create a common narrative help each family and a community as a whole to process the trauma. The connection between the people in the village community, their faith, and courage allowed our three interviewees to engage politically and socially and each of them in their own time and in their own way contributed to the 
development of the village, processing their individual and collective trauma, and creating interpersonal connections within the family and beyond.

\section{RESULTS AND DISCUSSION}

We found four main topics of trauma processing which enabled each generation to process their own aspects of traumatic past and to promote posttraumatic growth. We found that each generation addressed the same topic from a different point of view and from a different emotional or affective layer. The first topic is fear processing, the second is proactive behavior and development of social initiative, the third is the development of emotional vulnerability and safe relationships, and the fourth is making sense of the traumatic history. Those four pillars of trauma recovery are presented in the following tables. In the end, we extracted the main topics that characterize this family's posttraumatic growth and created its special mission.

1. Fear processing: The first generation experiences fear directly, triggered by fireworks, etc., the second about the external environment, while the third realizes that opposition in the outside world no longer represents any danger. 


\begin{tabular}{|c|c|c|}
\hline Grandmother Mary & Motherldaughter Jane & $\begin{array}{l}\text { Daughterl } \\
\text { granddaughter Sara }\end{array}$ \\
\hline $\begin{array}{l}\text { "(In 1948) I was } 21 \text { years } \\
\text { old, but by then I was } \\
\text { already scared; when } \\
\text { OZNA2 came up to } \\
\text { this house and killed } \\
\text { several people..." } \\
\text { "I still have this fear of } \\
\text { war. Wherever there are } \\
\text { wars, I disapprove of } \\
\text { them... War seems awful } \\
\text { to me.... if some kind of } \\
\text { war should break out, I } \\
\text { am afraid for the chil- } \\
\text { dren... That they should } \\
\text { ever experience this, } 1 / 4 . . \text { I } \\
\text { do not trust the system." }\end{array}$ & $\begin{array}{l}\text { "Mom still, if there } \\
\text { are any rockets (fire- } \\
\text { works), would back off, } \\
\text { she doesn't like that." } \\
\text { "It was the first time and } \\
\text { I was so scared because } \\
\text { the police came right in } \\
\text { to talk to me. I was home } \\
\text { alone at the time..., I was } \\
\text { afraid that I might be pre- } \\
\text { vented from graduating." }\end{array}$ & $\begin{array}{l}\text { "Let's say when I'm look- } \\
\text { ing for a new company } \\
\text { I always have to try to } \\
\text { work out what these } \\
\text { people are like, I dare not } \\
\text { speak freely in front of } \\
\text { everyone for fear that I } \\
\text { would not be accepted." } \\
\text { "So I am more afraid } \\
\text { when someone attacks } \\
\text { religion and defends } \\
\text { communism...." }\end{array}$ \\
\hline
\end{tabular}

2. Development of a proactive attitude: Immediately during and after the war, the first generation tried to do everything to keep the community connected and to inform the public about the truth of that time, despite the ban. The grandmother appeared as a speaker at a public memorial service for those killed after World War II. Her daughter was professionally engaged in this historical period, while her granddaughter, through her knowledge of these stories, formed a broad and open worldview.

2 OZNA: the secret political police of the Yugoslav communist regime. 
Journal of Nationalism, Memory \& Language Politics 15(1)

\begin{tabular}{|c|c|c|}
\hline Grandmother & Motherldaughter & $\begin{array}{l}\text { Daughterl } \\
\text { granddaughter }\end{array}$ \\
\hline $\begin{array}{l}\text { "Now I can say for } \\
\text { myself that I have got } \\
\text { rid of these horrors, but } \\
\text { I read about these things } \\
\text { many times, because I } \\
\text { am actually interested... } \\
\text { I have already read so } \\
\text { many of these books." } \\
\text { "I got the courage to } \\
\text { speak at public me- } \\
\text { morial service." } \\
\text { "When we had a po- } \\
\text { litical gathering in the } \\
\text { village, we, my husband } \\
\text { and I, both worked a } \\
\text { lot for the event." }\end{array}$ & $\begin{array}{l}\text { "What I took from my } \\
\text { parents: to endure even } \\
\text { in a public situation,..., } \\
\text { to dare to expose oneself, } \\
\text { to express one's opinion } \\
\text { and to accept the conse- } \\
\text { quences of that opinion." } \\
\text { "At that time, this } \\
\text { period of democratiza- } \\
\text { tion had already begun, } \\
\text { and I focused all my } \\
\text { thoughts on it..." } \\
\text { "...This party politics } \\
\text { absorbed me and I saw } \\
\text { my way of life. And it } \\
\text { also confirmed to me the } \\
\text { direction of my efforts." }\end{array}$ & $\begin{array}{l}\text { About her grandmother: } \\
\text { "When they got mar- } \\
\text { ried, they put a lot into } \\
\text { bringing the village } \\
\text { back to life, so that there } \\
\text { would be life, culture..." } \\
\text { About her mother: "Also } \\
\text { because my mother is } \\
\text { a historian, I knew a } \\
\text { lot of things, e.g., about } \\
\text { "Huda jama", the place } \\
\text { of a mass grave..." } \\
\text { "...I am very active in the } \\
\text { village, with the choir, } \\
\text { with the student society, } \\
\text { with the cultural society, } \\
\text { in the church,... with us it } \\
\text { was quite a way of life." } \\
\text { "The values that very } \\
\text { much characterize our } \\
\text { lives are religion and } \\
\text { home and homeland, } \\
\text { more broadly. That } \\
\text { stands out a lot." }\end{array}$ \\
\hline
\end{tabular}

3. Development of emotional vulnerability and safe relationships (motherhood, family connection): There was much distress and pain experienced through motherhood. The grandmother was in the hospital due to postpartum depression. The mother describes her childhood (before the war) as happy and relaxed but then experienced severe distress and exhaustion at the birth of her children, which she has managed to overcome on her own. The daughter, who does not yet have children, experiences her mother as present and resolute, which means that the mother managed to cope with motherhood despite the hardships. 
Možina, Erzar

Trauma and Community

\begin{tabular}{|l|l|l|}
\hline Grandmother & Motherldaughter & $\begin{array}{l}\text { Daughterl } \\
\text { granddaughter }\end{array}$ \\
\hline $\begin{array}{l}\text { "I mean, you usually } \\
\text { happily swaddle a baby. } \\
\text { But I cried because I } \\
\text { couldn't even manage } \\
\text { that. I lived with such } \\
\text { a torment at times that } \\
\text { it was unbearable." }\end{array}$ & $\begin{array}{l}\text { "For example, when I } \\
\text { gave birth, I had problems } \\
\text { would cry for no reason'.4 } \\
\text { I used to be convinced } \\
\text { that I was strong.., but } \\
\text { after that I just started } \\
\text { crying, for nothing." }\end{array}$ & $\begin{array}{l}\text { On the one hand, } \\
\text { lot of things that she } \\
\text { couldn't have in her } \\
\text { life on her own, and } \\
\text { never pampered us." } \\
\text { "I inherited from my } \\
\text { mother the fact that } \\
\text { you are always ready } \\
\text { to become better, that } \\
\text { you are always ready to } \\
\text { learn and still struggle } \\
\text { to get to know yourself." }\end{array}$ \\
\hline
\end{tabular}

4. Making sense of the traumatic history: All interviewees report the deep insights and growth they have made in accepting and telling stories.

\begin{tabular}{|c|c|c|}
\hline Grandmother & Mother/daughter & Daughter/granddaughter \\
\hline $\begin{array}{l}\text { "I'm happy today to know } \\
\text { all that I know; I still } \\
\text { pray for all those who are } \\
\text { at war in the world." } \\
\text { "I read and read all these } \\
\text { things to see what it was } \\
\text { like and to become more } \\
\text { 'courageous' now." }\end{array}$ & $\begin{array}{l}\text { "I had a slightly } \\
\text { broader view than the } \\
\text { purely childish one." } \\
\text { "When I listened } \\
\text { to all these stories, } \\
\text { it made it abso- } \\
\text { lutely easier for } \\
\text { me. I felt free." }\end{array}$ & $\begin{array}{l}\text { "On the one hand, I still have } \\
\text { a little bit of researcher in me, } \\
\text { such a child's curiosity in the } \\
\text { sense that I'm just interested." } \\
\text { "I experienced this quite natu- } \\
\text { rally. We talked about it a lot } \\
\text { here. That was a big part of } \\
\text { my life. We discussed this a lot } \\
\text { at Sunday lunches and other } \\
\text { events, it was quite natural." } \\
\text { "And now that I look at it } \\
\text { a little bit from a distance, } \\
\text { I think that's fine, because } \\
\text { when I come into a different } \\
\text { social group, I know that I } \\
\text { don't always have to adapt, } \\
\text { but that I can be who I am." }\end{array}$ \\
\hline
\end{tabular}


From the four pillars described above, we can extract three main themes that characterize our family.

\section{Main Themes of the Family}

In our family, we can see that in their narrative three content areas stand out: relationships/community, storytelling, and parenting. The basic point that intertwines through all these areas is the importance of knowing and understanding the complexness of the truth about what was happening. This family got its life mission out of the narrative. They learned that trauma empowers them to be active in healing society, returning life to their village, and caring for healthy, honest, and open relationships.

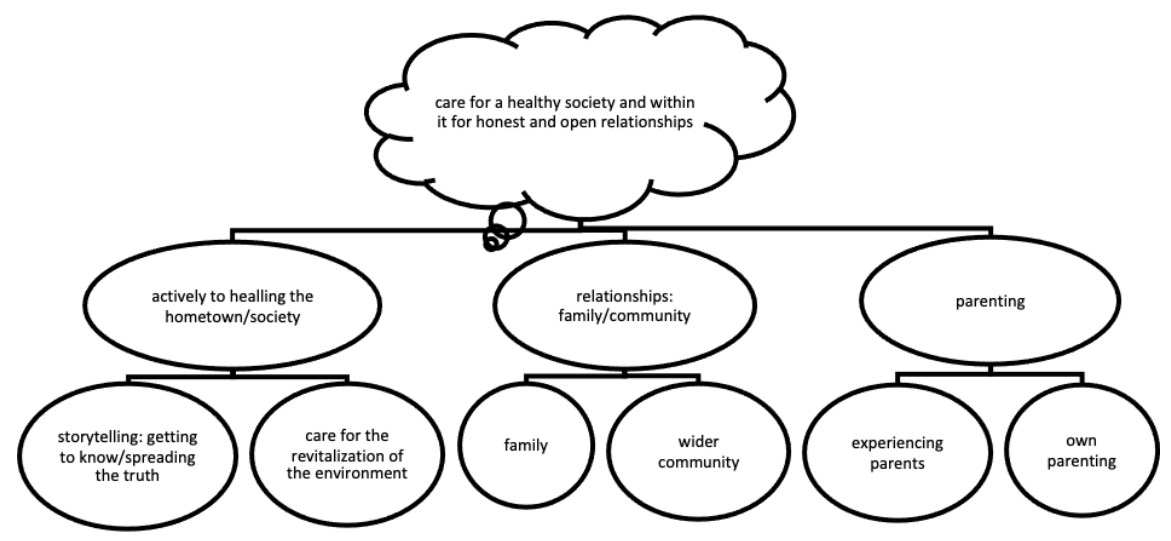

Fig. 3: Significance of traumatic experience for our family or its life mission (cloud) \& areas where meaning is created (ellipselcircle).

The described family managed to maintain strong intergenerational ties. Each generation creates stories that enable their members to understand each other and also to promote changes and encouragement. They also remained closely connected with their social environment. Thus, one can conclude that narrative which promotes relationships within the family and beyond, is a strong (social) resource of survival for this family and at the same time an important factor of post-traumatic growth. To create safer social environment traumatic past must be resolved, narrated, and emotionally regulated.

\section{Conclusion}

Trauma has greatly affected and determines the life of a family, its choices, and way of life. This article illustrates some of the ways of processing a traumatic 
history through maintaining a deep interpersonal connection, speaking courageously, and revealing the truth. Through social activity, the connection and security of the community and the individual in it were strengthened, and enabled the transformation of painful and difficult traumatic experiences into courage and emotional security. We found that the ability to narrate their experience was one of the most powerful and fruitful methods of trauma processing. The family that is presented in the article resolved traumatic background by remaining together and gradually developing the courage to openly address past issues even in a broader social context. Four pillars of posttraumatic growth: fear processing (1), proactive behavior and development of social initiative (2), development of emotional vulnerability and safe relationships (3), and making sense of the traumatic history (4), enabled the family to liberate the third generation of traumatic past. The representative of the third generation is now more secure and able to develop sovereignty in relation even to peers of different ideological backgrounds.

\section{References}

Albeck, J. H. (1994). Intergenerational consequences of trauma: Reframing traps in treatment theory-A second-generation perspective. In E. B. Williams \& J. F. Sommer, Jr. (Eds.)... Family Process, 29(3), 325-339.

Bezo, B. and Maggi, S. (2015). Living in »survival mode«. Interdenerational transimission of trauma from the Holodomor genocide of 1932-1933 in Ukraine. Social Science \& Medicine, 134, 87-94.

Cvetek, R. (2010). Bolečina preteklosti: Travma, medosebni odnosi, družina, terapija. Celje: Celjska Mohorjeva družba: Društvo Mohorjeva družba.

Dežman, J. (2004). Moč preživetja: sprava z umorjenimi starši. Celovec, Ljubljana, Dunaj: Mohorjeva.

Dežman, J. (2012). Slovenia and the criminal burden of Titoism. In J. Juhant \& B. Žalec (Eds.), Reconciliation: The way of healing and growth (pp. 221-232). Munster, Germany: Lit Verlag.

Erzar, T. (2015). Nedovoljeno, nezaželeno in nepriznano žalovanje: analiza fenomena v luči štirih slovenskih dokumentarnih filmov o otrocih in o sirotah druge vojne [Disenfranchised, unwanted and unrecognized grief: Analysis of the phenomenon based on four documentary films about Slovenian wartime children and orphans]. Bogoslovni vestnik, 75(2), 275-285.

Fredricson, B. (2009). Positivity: Top-notch Research Reveals the 3 to 1 Ratio That Will Change Your Life. New York. Random House.

Gillihan, S. J. (2016). 7 Ways Survivors Can Grow After Trauma. Psychology Today. https:// www.psychologytoday.com/intl/blog/think-act-be/201610/7-ways-survivors-can-growafter-trauma 


\section{Journal of Nationalism, Memory \& Language Politics 15(1)}

Hirsch, M. (2008). The Generation of Postmemory. Poetics Today: International Journal for Theory and Analysis of Liteature and Communication, 29 (1), 103-128.

Kahane-Nissenbaum, Melissa C. (2011). Exploring intergenerational transmission of trauma in third generation holocaust survivors. Doctorate in Social Work (DSW) Dissertations. 16.

Kestenberg, J. S. in M. (1982). The background of the study. V M S. Bergman in M. E. Jucovy (Eds.), Generations of Holocaust (p. 33-45). New York: Basic Books.

Kompan Erzar, K., Erzar, T. (2012). Healing the trauma of postwar killings in Slovenia. in: Juhant, J. (ed.), Žalec, B. (ed.). Reconciliation: the way of healing and growth, (Theologie OstWest, Bd 16). Zürich; Münster. p. 259-266.

Kompan Erzar, K. (2017) The Flowers of Compassion: A Trauma-Informed Artistic Event Involving Three Generations of Slovenians. Canadian Art Therapy Association Journal, 30(1), 41-49.

Landau, J. in Saul, J. (2004). Facilitating Family and Community Resilience in Response to Major Disaster. V F. Walsh in M. McGoldrick (ur.), Living beyond loss: Death in the Family (str. 285 - 309). New York: W. W. Norton \& Company.

McGoldrick, M. (2004). Living beyond Loss. Death in the family. New York. Norton.

McGoldrick, M. (2011). The Genogram Journey: Reconnecting with Your Family. New York: W. W. Norton \& Company.

Mendelsohn, D. (2006). The lost: A Search for Six of Six Million. New York: Harper.

Možina, M. (2009). Etika udeleženosti: problem ni, kdo ima prav ali kaj je res, problem je zaupanje. V: Slovenska revija za psihoterapijo Kairos, vol. 3 (3-4), 115 - 149.

Kellerman, N. P. F. (2009). Holocaust trauma: Psychological effect and treatment. New York Bloomington: iUniverse, Inc.

Kompan Erzar, K. (2019). Družina, vezi treh generacij [Family, bonds of three generations]. Ljubljana: Družina.

Lev-Wiesel, R. (2007). Intergenerational Transmission of Trauma across Three Generations. Qualitative Social Work, vol. 6, 75-94.

Možina, J. (2019). Slovenski razkol [The Slovenian schism]. Ljubljana. Mohorjeva družba.

Porges, S. (2011). The Polyvagal theory: Neurophysiological Foundations of emotions, Attachment, Communication, and Self-regulation. New York. Norton.

Richman, S. (2002). A Wolf in the Attic: The legacy of a hidden child of the holocaust. New York. Haworth.

Rolland, J. S. (2004). Family Legacies of the Holocaust: My Journey to Recover the Past. V F. Walsh in M. McGoldrick (ur.), Living beyond loss: Death in the Family (p. 423 - 428). New York: W. W. Norton \& Company.

Rosner, E. (2017). Survivor Cafe. Berkeley: Counterpoint.

Sagi-Schwartz, A. (2003). Introduction to the special issue: Extreme life events and catastrophic experience and the development of attachment across the life span. Attachment of Human Development, vol. 5 (4), 327 - 329.

Sigel, J. J. and Weinfeld, M. (1989) Trauma and Rebirth: Intergenerational Effects of the Holocaust. New York: Praeger.

Scheff, T. (2000). Shame and the Social Bond. Sociological Theory: vol 18 (1), 84-99. 
Van der Kolk, B. A., McFarlane, A. C., \& Weisaeth, L. (Eds.). (1996). Traumatic stress: The effects of overwhelming experience on mind, body, and society. New York. Guilford Press.

Van der Kolk, B. (2014). The Body Keeps the Score: Mind, brain and Body in the Transformation of Tauma. UK: Penguin Books.

Weingarten, K. (2004). Witnessing the effects of political violence in families: mechanisms of intergenerational transmissions and clinical interventions. Journal of Family and Marital Therapy, vol. 30 (1), 45-59.

Werner-Lin, A. in Moro, T. (2004). Unacknowledged and Stigmatized Losses. In F. Walsh in M. McGoldrick (ur.), Living beyond loss: Death in the Family (str. 247 - 271). New York: W. W. Norton \& Company.

Wigram, J. (1994). Narrative completion in the treatment of trauma. Psychotherapy Theory, Research, Practice, Training, 31(3), 415-423.

Wolynn, M. (2017). It Didn't Start With You: How Inherited Family Trauma Shapes Who We Are And How To End The Cycle. New York: Penguin Book. 